\title{
Three Libri missarum of early Lutheran Germany: some reflections on their repertory
}

\author{
Carlo Bosi
}

By the time Johann Petreius, Hieronymus Formschneider and Georg Rhau issued their important mass collections (1539, 1539 and 1541, respectively), all three men were already well-established and successful printers. ${ }^{1}$ Both Petreius and Rhau were accomplished musicians; Rhau was even a composer; both could therefore act as editors and publishers of their anthologies. By contrast, Formschneider, whose family name was Andreae, was 'only' a very gifted type- and wood-cutter, as his sobriquets Formschneider ('type-cutter') and Grapheus ('graphic artist' or 'scribe') suggest. Formschneider acted exclusively as printer and had thus little or no control on the contents of 'his' publications; indeed, it is even doubtful whether he possessed any musical knowledge. ${ }^{2}$ However, his achievements and reputation as a proficient artisan attracted music publishers, such as Hans Ott, who commissioned him to print several editions in 1538, but also the Missae tredecim quatuor vocum, published in 1539, all funded and edited by Ott. At the start of the lengthy dedicatory letter prefaced to the tenor partbook, Ott states that with this mass collection he wanted to make available 'monuments' by celebrated composers not only so that they might be in the hands of many, but also in order to preserve them for posterity. ${ }^{3}$

A synoptic comparison of the three collections (see Table 6.1) shows that while all three of them draw for the most part from a well-established international repertory, the only overlap concerns the two early Josquin masses L'homme armé super voces musicales and Fortuna desperata, found in both Petreius and Formschneider/Ott. This has led Michael Meyer to hypothesise that the two publishers perhaps intentionally aimed at issuing two complementary Josquin repertories. ${ }^{4}$ However, as Stephanie Schlagel has shown, whereas Petreius' copy is based on one of Petrucci's editions Misse Josquin liber primus, containing both of them, Ott had to rely on incomplete and partly faulty copies. ${ }^{5}$ On the other hand, Josquin is completely absent from Rhau's book. However, Rhau does transmit two masses based on chansons by Josquin: the Missa Adieu mes amours by Adam Rener and the Missa Baisez moy by Petrus Roselli, and one based on a chanson-mass attributed in some sources to Josquin (Isaac's Missa Une Musique [sic] de Biscaye). ${ }^{6}$ For the rest, Josquin is most heavily represented in Petreius' book, with six masses out of fifteen. Of the thirteen masses in Formschneider, Ott (or his sources) ascribes five to Josquin. But of these ascriptions, two are certainly incorrect: the mass Sub tuum praesidium is by Pierre de la Rue, while the Missa Da pacem is attributed to Josquin only in peripheral sources, such as Toledo 19, whereas more reliable manuscripts, such as Munich 7, ascribe it to Noël Bauldeweyn, an ascription now commonly accepted. ${ }^{7}$ Interestingly, in the contratenor partbook of Formschneider/ Ott, the Missa Sub tuum praesidium is ascribed to 'Petrus de la Rue', ${ }^{8}$ whereas the ascription of Missa Da pacem to Josquin is only found in the index in the tenor and at the beginning of the 'Kyrie' in the discantus partbooks. 
Table 6.1 Synopsis of the three mass collections

\begin{tabular}{|c|c|c|}
\hline Petreius & Grapheus [Formschneider] & Rhau \\
\hline $\begin{array}{l}\text { Liber quindecim missarum } \\
\text { (Nuremberg, 1539) }\end{array}$ & $\begin{array}{l}\text { Missae tredecim quatuor vocum, } \\
\text { publ. and ed. Hans Ott } \\
\text { (Nuremberg, 1539) }\end{array}$ & $\begin{array}{l}\text { Opus decem missarum quatuor } \\
\text { vocum, ed. Georg Rhau } \\
\text { (Wittenberg, 1541) }\end{array}$ \\
\hline $\begin{array}{l}\text { 1. Josquin, L'homme armé super } \\
\text { voces musicales }\end{array}$ & 1. Obrecht, Ave regina [caelorum] & $\begin{array}{l}\text { 1. Rener, Missa Adieu mes } \\
\text { amours }\end{array}$ \\
\hline 2. Josquin, La sol fa re mi & 2. Josquin, Fortuna [desperata] & 2. Senfl, Missa Nisi Dominus \\
\hline 3. Josquin, Super Gaudeamus & 3. Brumel, Bon temps & $\begin{array}{l}\text { 3. Sampson, Missa Es solt ein } \\
\text { Megdlin holen wein }\end{array}$ \\
\hline $\begin{array}{l}\text { 4. Josquin, Super Fortuna } \\
\text { desperata }\end{array}$ & 4. Isaac, Salva nos & $\begin{array}{l}\text { 4. Isaac, Missa Une Musicque } \\
\text { de Biscay }\end{array}$ \\
\hline 5. Josquin, De beata virgine & $\begin{array}{l}\text { 5. Josquin, L'omme armé [super } \\
\text { voces musicales] }\end{array}$ & 5. Rener, Missa Octavi Toni \\
\hline $\begin{array}{l}\text { 6. Brumel, Festivale [Je n'ay } \\
\text { dueil] }\end{array}$ & 6. Isaac, Frölich wesen & 6. Roselli, Missa Baisez-moy \\
\hline 7. Isaac, O praeclara & 7. Josquin, Pange lingua & 7. Isaac, Missa Carminum \\
\hline $\begin{array}{l}\text { 8. Hellinck, Hercules dux } \\
\text { Ferrariae }\end{array}$ & 8. La Rue, Cum iocunditate & $\begin{array}{l}\text { 8. Stahel, Missa brevis. } \\
\text { Vuinken ghy syt grone }\end{array}$ \\
\hline 9. La Rue, Tous les regrés & $\begin{array}{l}\text { 9. Josquin [but more likely } \\
\text { Bauldeweyn], Da pacem }\end{array}$ & $\begin{array}{l}\text { 9. Rener, Missa Dominicalis, } \\
\text { (KGSA)/ Brumel, [Missa } \\
\text { De Beata Virgine] (C) }\end{array}$ \\
\hline 10. Layolle, Adiu mes amours & $\begin{array}{l}\text { 10. Josquin [la Rue], Sub tuum } \\
\text { praesidium }\end{array}$ & 10. Pipelare, Missa De Feria \\
\hline 11. Josquin, Ave maris stella & 11. La Rue, O gloriosa & \\
\hline $\begin{array}{l}\text { 12. Breitengraser, Dominicale } \\
\text { [sic] }\end{array}$ & 12. Obrecht, Petrus apostolus & \\
\hline $\begin{array}{l}\text { 13. Brumel, À l'ombre d'ung } \\
\text { buissonet }\end{array}$ & 13. La Rue, De S. Antonio & \\
\hline $\begin{array}{l}\text { 14. Okeghem, Missa cuiusvis } \\
\text { toni }\end{array}$ & & \\
\hline $\begin{array}{l}\text { 15. Moulu, Missa duarum } \\
\text { facierum E plus. Canitur enim } \\
\text { vel cum pausis vel sine pausis }\end{array}$ & & \\
\hline
\end{tabular}

It is intriguing to note, in addition, that three masses in Petreius' book apparently allude to Josquin: in two cases to songs (the Missae Adiu [sic] mes amours by Francesco de Layolle, and $\grave{A}$ l'ombre d'ung buissonet by Antoine Brumel), in one case to a mass (the Missa Hercules $d u x$ Ferrariae by Lupus Hellinck). ${ }^{9}$ However, one of these masses actually based on a composition by Josquin is Brumel's mass À l'ombre d'ung buissonet in Petreius. Layolle's Missa Adiu [sic] mes amours is not based on Josquin's famous song, but 'is a parody of Mouton's chanson which uses the same melody as Josquin's better-known setting'. ${ }^{10}$ In Hellinck's Missa Hercules dux Ferrariae, the hexachord syllables used by the composer as cantus firmus do not match its title. Rather, Bonnie Blackburn has suggested that the title was added by Moderne, who first published the work in $1532 .{ }^{11}$ Moderne, however, did not just invent this ascription because a mass anthology containing works attributed to Josquin promised to sell well; the overall structure of the mass, including the way the cantus firmus is presented, closely resembles Josquin's more famous work. If, on the other hand, Petreius' choice of this mass was motivated not only by the marketability of Josquin, but also by the intention to provide an exemplary instance of a soggetto cavato dalle parole, then he fell short of his target, since, as we noted already, the suggested hexachord syllables do not match 


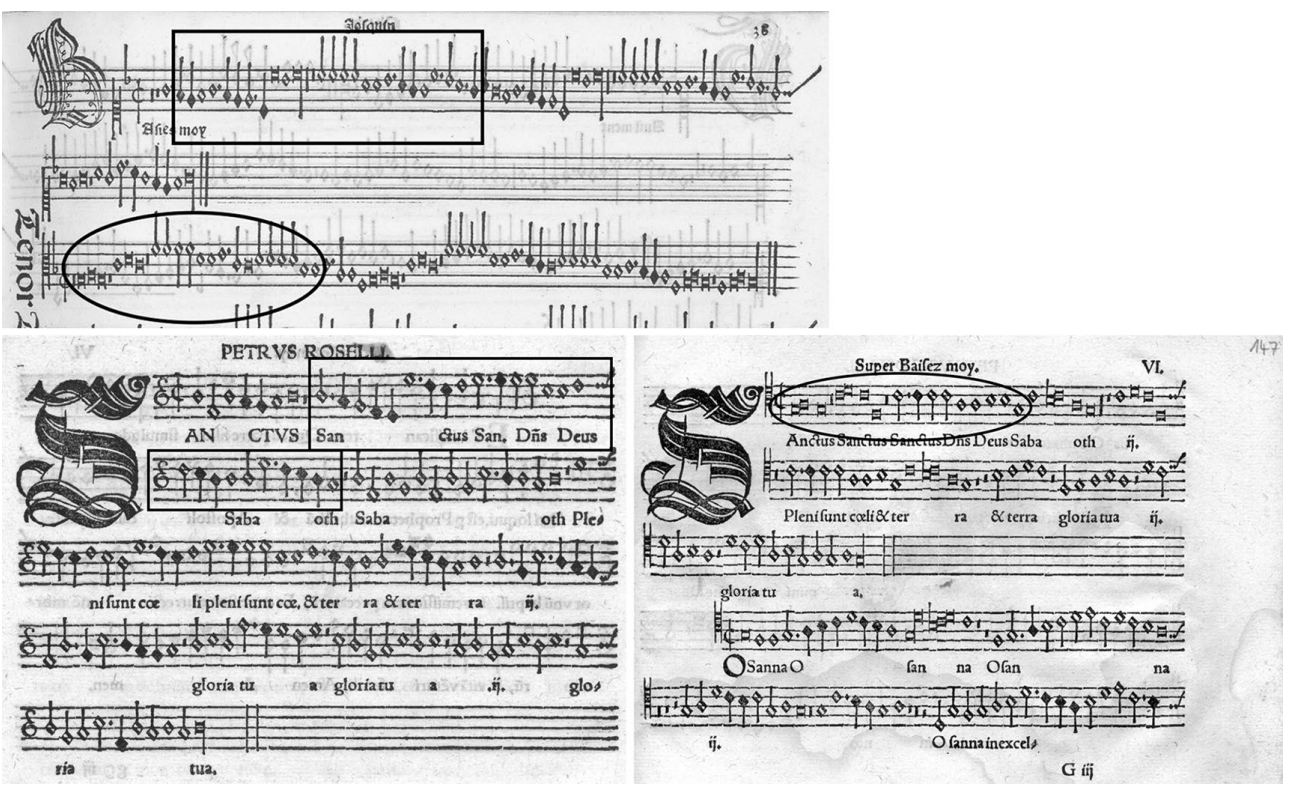

Figure 6.1 Comparison between Josquin, Basiés-moy in Canti B, fol. $38^{\mathrm{r}}$ and Petrus Roselli, Missa Baisez-moy in Rhau 1541: Sanctus, discantus (fol. 197v) and tenor parts (fol. 147 r).

Sources: Paris, Bibliothèque nationale de France, Rés 539 (Canti B); Kassel, Landesbibliothek und Murhardsche Bibliothek der Stadt, $4^{\circ}$ Mus. 63/1 (Rhau 1541).

the syllables of the title. He evidently copied the title from Moderne's Liber decem missarum, his likely source for this mass and for Layolle's Missa Adieu mes amours. ${ }^{12}$ However, the apparent suggestion that these works were written by Josquin is a mirage. The masses by Layolle and Isaac (printed by Rhau) are based not on Josquin's songs, but on the melodies he used for his arrangements. In Roselli's Missa Baisez-moy, on the other hand, material from Josquin's eponymous canonic chanson, as it appears in Petrucci's Canti B, is indeed cited, but only in the Sanctus (see Figure 6.1); in Kyrie II, Roselli's quotes Quant je vous voye, another song by Josquin. ${ }^{13}$ Despite the fact that these masses only have a tenuous link to Josquin, the suggestion that they were genuine works by the master was probably important for their relatively wide diffusion. ${ }^{14}$

\section{Rhau's sources}

The presence of a mass by Rener in Rhau's Opus decem missarum is easy to explain, given that the composer, born in Liège and trained at Maximilian's court, served in the Electoral Saxon court chapel and was involved in preparing the manuscripts (now in Jena) compiled for the Saxon chapel. ${ }^{15}$ His masses Adieu mes amours and Octavi Toni, however, are otherwise only preserved in the incomplete partbooks Leipzig 51; although these are later than Rhau's print, Noblitt has suggested that the Leipzig manuscripts may have been copied from a now lost Formschneider/Ott anthology ${ }^{16}$ Rhau's 1541 edition is also the earliest source for the other mass by Rener, Missa Dominicalis; the only other source is the manuscript partbooks Rostock XVI-49, copied at Hamburg around $1566 .{ }^{17}$ In the case of Isaac's mass Une Musque de Biscaye, Rhau may have had access to Berlin 40021, a large manuscript possibly compiled in Torgau, which is also the main source for this composition. Indeed, his transmission only shows few and insignificant variants compared with the earlier 
manuscript, apart from the curious 'corruption' of the title from Musque to Musicque. ${ }^{18}$ Rhau's reliance on local sources for the other mass attributed to Isaac, Missa Carminum, is evident, since the reading of this work in the Opus decem missarum is nearly identical to its concordance in Jena $36 .{ }^{19}$

On the other hand, the Missa Baisés-moy by Petrus Roselli or 'Rouseli', first published in Antico 1516, was subsequently copied in several sources redacted by Johann Walter and his collaborators in Torgau just before or around the time that Rhau published his mass collection. ${ }^{20}$ It is revealing that Rhau's dedicatory epistle is directed to the city council of Torgau as patron of the local Latin school, given that the Opus decem missarum was conceived for the musical training of schoolboys. ${ }^{21}$ Rhau's transmission of Roselli's mass is nearly identical to Antico's (see Figure 6.2). Even his text underlay seems to follow Antico quite closely, as shown, for example, by syllable division in melismatic passages of long texted movements, such as the Gloria or Credo (see Figure 6.3). ${ }^{22}$ On the other hand, Rhau's readings are quite different from those of the later transmission (c. 1540-1545) in the Torgau choirbooks Berlin 40013, Weimar B and Gotha A.98. ${ }^{23}$ Gotha A.98, for instance, has minor rhythmical variants, and an entirely different passage at the end of Kyrie II in the discantus (see Figure 6.4). In the printed editions, the Cum sancto spiritu is a subsection in triple time following directly after the Qui tollis, whereas in the Torgau manuscripts it is an autonomous section, musically distinct from that given by Antico and Rhau. Moreover, while the Benedictus is a duet (tenor and bassus) in Antico and Rhau, in all Torgau choirbooks it has completely different music for four voices. Additionally, in none of the Walter choirbooks does Roselli's mass carry the title Baisez-moy; instead, it is called simply Missa Petri Roselli. ${ }^{24}$ It thus seems likely either that Walter and his copyists had at least partly different exemplars than Rhau, or that they tinkered with the mass as found in Antico in
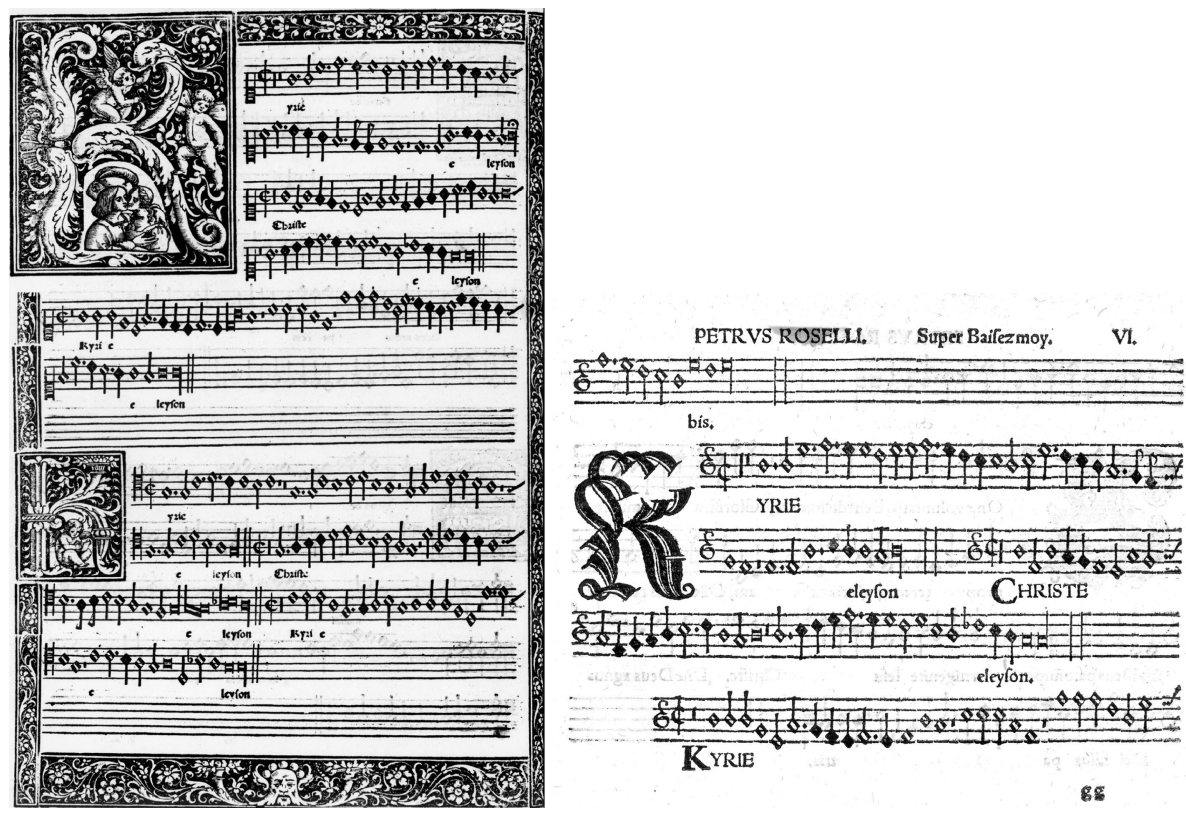

Figure 6.2 Kyrie, discantus, from Petrus Roselli, Missa Baisez moy in Antico 1516, fol. 140v (left) and Rhau 1541, fol. $195^{\mathrm{r}}$ (detail, right).

Sources: London, British Library K.9.a.12 (Antico 1516); Kassel, Landesbibliothek und Murhardsche Bibliothek der Stadt, $4^{\circ}$ Mus. 63/1 (Rhau 1541). 
order to produce what they thought would be more satisfying solutions, such as a fuller sonority in the four-voice Benedictus. Similar 'filling-in' of reduced scoring does not occur in the few other masses by older masters transmitted by the Walter choirbooks, such as the Missa super Nisi dominus by Senfl in Gotha A.98. These Torgau versions of the Roselli mass also deviate from the other known manuscript transmission in San Petronio (San Petronio A.31 and A.46.). ${ }^{25}$ The copy in the incomplete partbooks Leipzig 51, probably compiled in Leipzig about fifteen years later than Rhau 1541, is largely dependent on it. But Rhau did not just passively copy Roselli's mass from Antico: in at least one case he slightly changed the rhythm without altering the substance: at the words 'Et expecto' in the Et in spiritum sanctum section of the Credo (see Figure 6.5), towards the end of a triple-time passage, he resolves two blackened ligatures in the bassus, changing blackened sb-sb b-b into blackened $s b-b$ b-sb, thereby assimilating this voice to the analogous passage in the discantus and tenor. One might suppose that Rhau did not have the necessary types, but in fact the
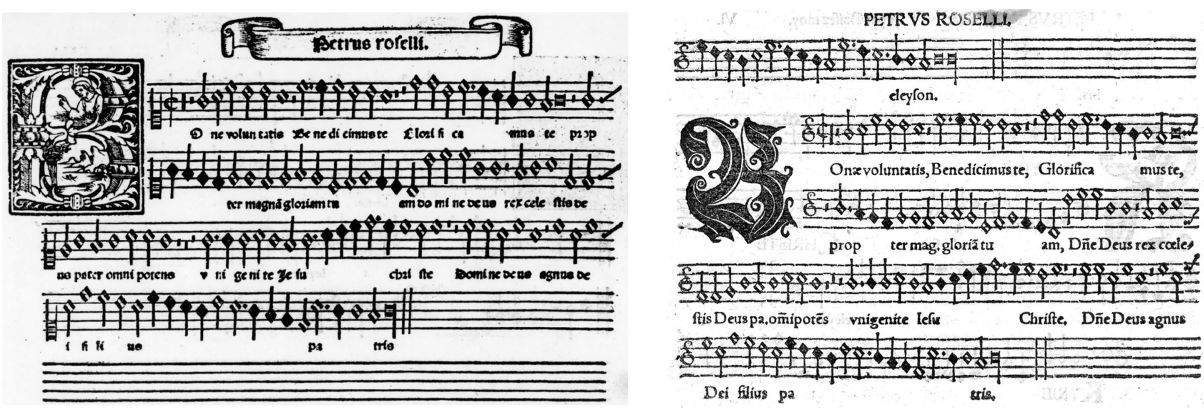

Figure 6.3 Gloria, discantus, from Petrus Roselli, Missa Baisez moy in Antico 1516, fol. $141^{\mathrm{v}}$ (left) and Rhau 1541, fol. $195^{\mathrm{v}}$ (right).

Sources: London, British Library K.9.a.12 (Antico 1516); Kassel, Landesbibliothek und Murhardsche Bibliothek der Stadt, $4^{\circ}$ Mus. 63/1 (Rhau 1541).
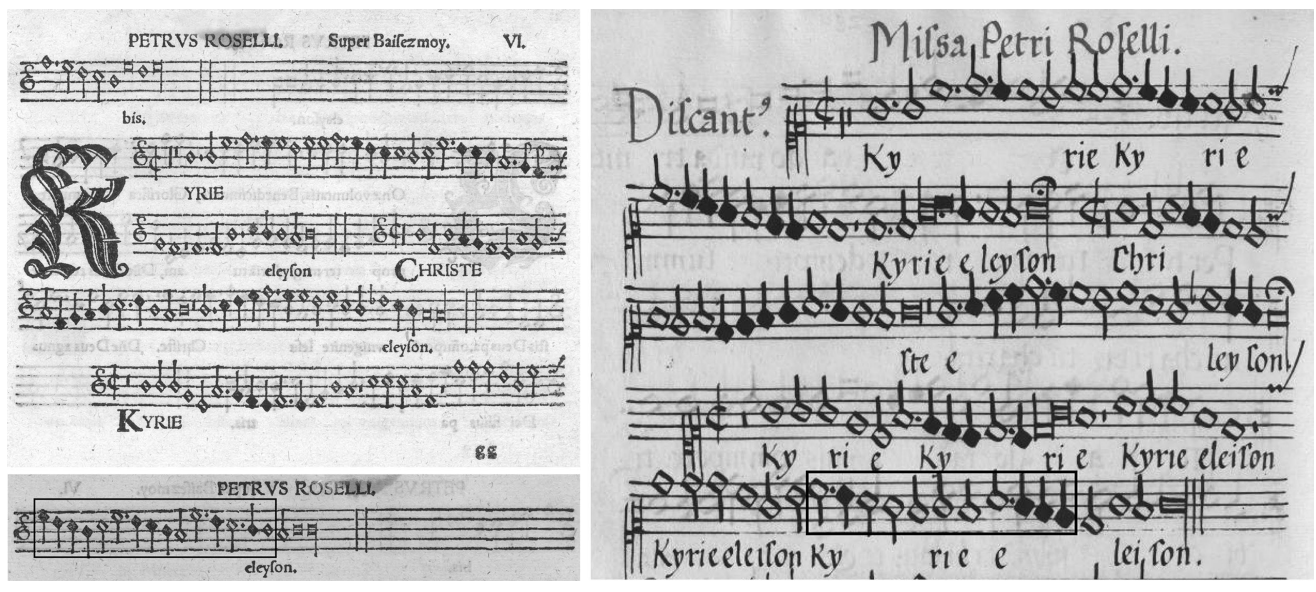

Figure 6.4 Kyrie, discantus, from Petrus Roselli, Missa Baisez moy in Rhau 1541, fol. 195 ${ }^{\text {r-v }}$ (left) and Gotha A.98, fol. 288v, with framed out variant at the end of Kyrie II.

Sources: Kassel, Landesbibliothek und Murhardsche Bibliothek der Stadt, $4^{\circ}$ Mus. 63/1 (Rhau 1541); Gotha, Forschungsbibliothek Gotha, Schloss Friedenstein, Chart. A.98 (Gotha A.98). 

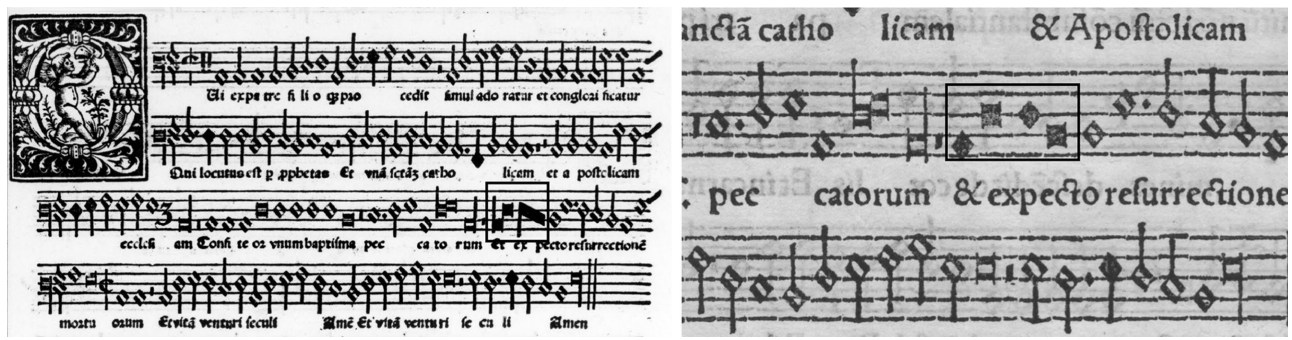

Figure 6.5 Et expecto, bassus, from Petrus Roselli, Missa Baisez moy in Antico 1516, fol. $145^{\mathrm{r}}$ (left) and Rhau 1541, fol. $186^{\mathrm{v}}$, with framed out ligature variant.

Sources: London, British Library, K.9.a.12 (Antico 1516); Kassel, Landesbibliothek und Murhardsche Bibliothek der Stadt, $4^{\circ}$ Mus. 63/1 (Rhau 1541).

ligatures in question occur several times in his print. We may therefore conclude that this change was an editorial intervention. This conclusion is indirectly corroborated by the fact that the Walter choirbooks have the same reading here as Antico.

Rhau's 1541 book has a further concordance with Antico 1516: the Credo from the Missa De beata virgine by Antoine Brumel. ${ }^{26}$ Rhau substituted the Credo of Brumel's mass for Rener's Missa Dominicalis. The only other known source for this mass, the much later Rostock XVI-49, includes Rener's own Credo, though in an incomplete form, stopping at 'Et homo factus est'. If Rener's mass was only transmitted with this incomplete Credo, it is not surprising if Rhau wished to supplement it with a full movement. As we have seen, he probably had a copy of Antico 1516, which opens with Brumel's mass, even if Brumel's Credo is quite long and undermines Rhau's wish to provide short masses, as he states in his preface (see below). However, Brumel's Credo as well as Rener's Gloria and (incomplete) Credo are all based on chant ordinary melodies in the fourth mode, so that Rhau's choice was probably motivated by modal considerations. ${ }^{27}$ Rhau's transmission of Brumel's Credo, including text underlay, is also essentially identical with Antico's. However, at mm. 173-174, Rhau splits a breve in the discantus to accommodate all the syllables of 'Qui cum patre \& filio' (see Figure 6.6). This is also reflected in the transmission in Capp. Sist. 16; though very close to Antico and Rhau, in a couple of cases its cadences are more ornamented (see Figure 6.7). In another case, at the end of the Patrem section in the tenor, Rhau repeats the words 'factus est' for the last two notes, a semibreve and a final longa, untexted in the other sources; in order to accommodate the three syllables, he splits the semibreve into two minims. This is one of numerous cases where Rhau repeats portions of text, a repetition which the other transmissions may imply, as is often the case, without specifying it. This may represent further evidence of the didactic ambition of Rhau's edition. ${ }^{28}$ Further evidence of Rhau's pedagogic aim is provided by the fact that in the bassus, he explicitly notates all Bs in the melodic gesture $A-B-A$ as $f a$, that is, with a $b$ sign. ${ }^{29}$ This is not simply a slavish application of the rule of fa supra la, since analogous gestures in the discantus are left uninflected. Rather, in the bassus this gesture is always part of a recurrent motive directly taken from Credo I, on which Brumel's mass movement is based, a motif often reached via imitation at a fifth from the upper voices.

By contrast, the reading of Senfl's Missa Nisi dominus is very close to that transmitted by Walter's workshop in Nuremberg 83795, Gotha A.98 and Berlin $40013 .{ }^{30}$ It is possible that Rhau and Walter had the same or very similar exemplars at their disposal. ${ }^{31}$ The only minor divergences are lesser rhythmic variants with no major consequence on the 
music itself. Occasionally, however, Rhau shows a humanistic concern for consistent text declamation, especially by the repetition of text fragments. Contrary to all Walter sources, for instance, he begins the last Kyrie declamation of Kyrie II (b. 13) with a crotchet rest (see Figure 6.8), echoing the two preceding declamations, which also begin with a rest and which, moreover, represent transpositions of the same motivic material. The Missa De Feria by Matthaeus Pipelare was also available in a source close to Rhau: Jena 21, one of the Alamire choirbooks owned by Duke Frederick the Wise, compiled around 1521-1525. Rhau's reading is essentially identical to that in Jena $21 .^{32}$ Rhau probably selected this mass for his publication mainly because of its concision, since, as he states in the dedicatory letter, he chose the ten masses of his collection not only on account of their elegance and sweetness, but also due to their brevity. ${ }^{33}$ It is not difficult to imagine that Rhau copied this mass directly from Jena 21, given that the Alamire manuscripts that had belonged to Frederick the Wise were housed until 1547 at the All Saints Church in Wittenberg, and were thus easily available to him. ${ }^{34}$ In any case, no other sources of this mass are known. Finally,
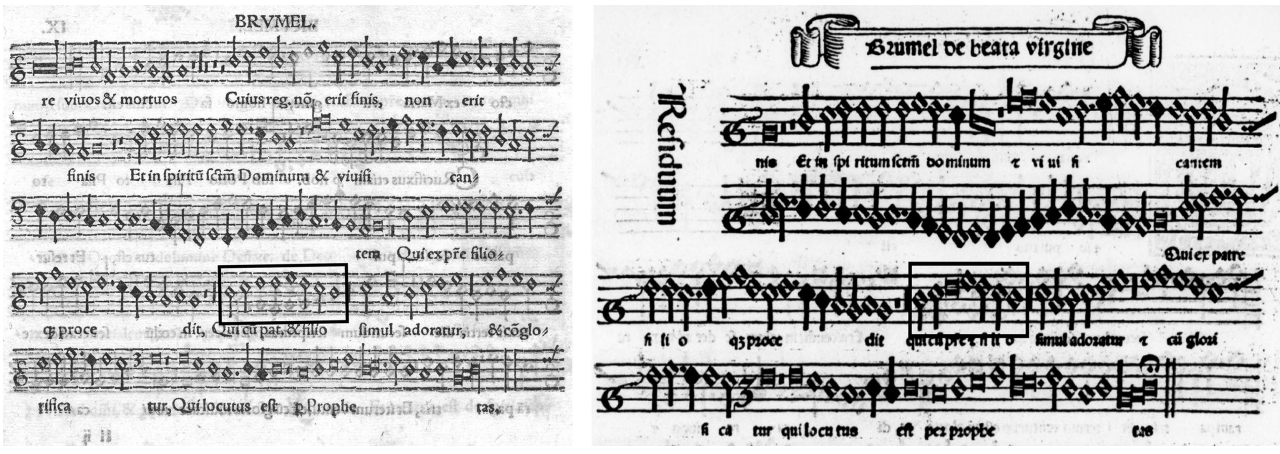

Figure 6.6 Crucifixus (detail), discantus, from Antoine Brumel, Credo of the Missa De beata virgine replacing the Credo of Adam Rener, Missa Dominicalis in Rhau 1541, fol. 212v (left) and the same place in Antico 1516, fol. 12v (right).

Sources: Kassel, Landesbibliothek und Murhardsche Bibliothek der Stadt, $4^{\circ}$ Mus. 63/1 (Rhau 1541); London, British Library, K.9.a.12 (Antico 1516).
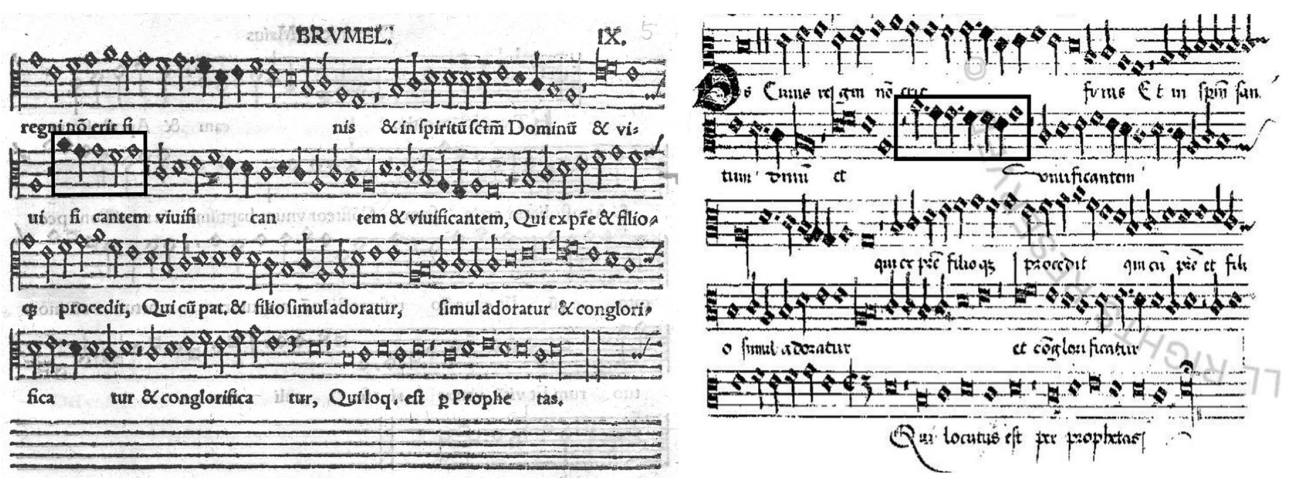

Figure 6.7 Crucifixus (detail), tenor, from Antoine Brumel, Credo of the Missa De beata virgine replacing the Credo of Adam Rener, Missa Dominicalis in Rhau 1541, fol. $202^{\mathrm{r}}$ (left) and the same place in Capp. Sist. 16, fol. 14v (right).

Sources: Kassel, Landesbibliothek und Murhardsche Bibliothek der Stadt, $4^{\circ}$ Mus. 63/1 (Rhau 1541); Rome, Biblioteca Apostolica Vaticana, MS Cappella Sistina 16 (Capp. Sist. 16). 

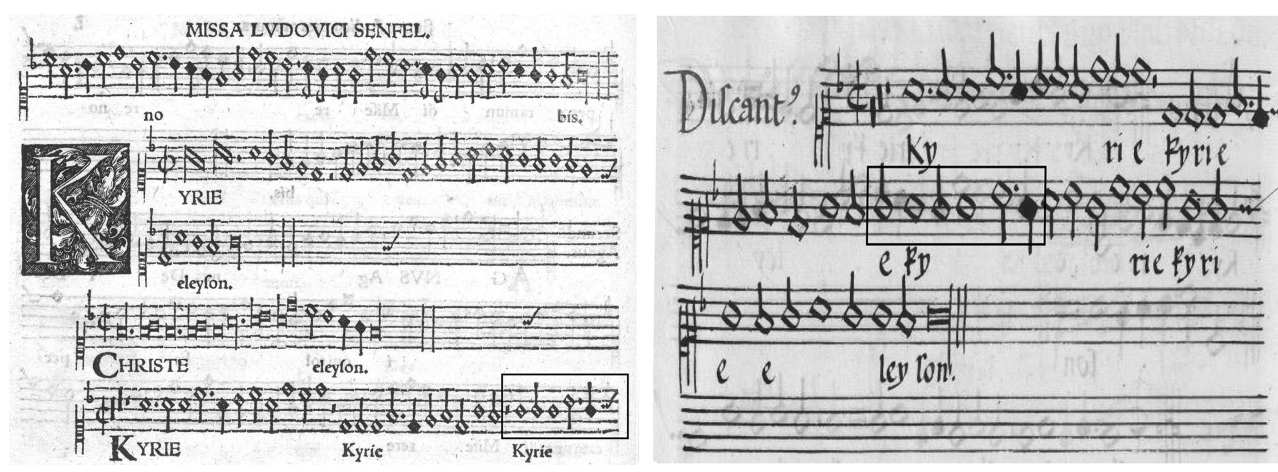

Figure 6.8 Kyrie (detail), discantus, from Ludwig Senfl, Missa Nisi Dominus in Rhau 1541, fol. $176^{\mathrm{v}}$ (left) and Gotha A.98, fol. 302v .

Sources: Kassel, Landesbibliothek und Murhardsche Bibliothek der Stadt, $4^{\circ}$ Mus. 63/1 (Rhau 1541); Gotha, Forschungsbibliothek Gotha, Schloss Friedenstein, Chart. A.98 (Gotha A.98).

the masses by the mysterious 'Sampson' and by Johann Stahel, both unica, might have been available to the publisher through his own networks: Stahel was a local glory, most of whose surviving works appear in editions by Rhau; 'Sampson' was probably active in central Germany, since the song upon which his mass is based opens the edition Berg and Neuber 1549.

\section{Three German editions in a wider European context}

It is likely that the three masses that seem to refer to Josquin were available at some point in Wittenberg. Isaac's international fame, as well as the strong Central European and German transmission of many of his works, together with Rener's local significance, are probably sufficient to explain Rhau's choice. ${ }^{35}$ As for Roselli's mass, it is likely, as we have seen, that Rhau had access to Antico's 1516 edition, and used this rather than one of the Torgau manuscripts, or their sources, compiled under the aegis of Johann Walter in or around 1540. But, of course, Rhau could just as well have chosen another mass, such as the Missa Baisés-moy by Mathurin Forestier, more closely modelled on Josquin's song, and also transmitted in a local source, Jena 4, held at Wittenberg until around 1547, like the other Alamire choirbooks now in Jena. ${ }^{36}$ The only plausible explanation for Rhau's choice is that Roselli's mass, like most of the others in Rhau's book, is compact and largely syllabic, especially in the Gloria and Credo, elements that made it suitable for young students. Despite these qualities, it is perhaps surprising that Roselli's work attracted such attention in the Torgau-Wittenberg orbit.

The Missa Baisés moy is the only known work of this composer who is now rather obscure. Almost nothing is known of his life. He may perhaps be identified with the singer Pietro Rossello, active in the chapel of Ercole I d'Este in Ferrara between 1499 and 1502; to judge from the alternative spelling of his surname (Rouseli), he was probably French. ${ }^{37}$ He might have been related to Rémy Roussel (Remigius Ruffus), canon at the cathedral of Tours, to whom Attaingnant dedicated a collection of works by Pierre de Manchicourt in $1539 .{ }^{38}$ Perhaps he was related to another Rémy Roussel, to whom several humanistic and religious works published at Paris between 1515 and 1517 were dedicated. From some of these, it emerges that this Rémy Roussel - for chronological reasons probably different from the canon in Tours - was a professor from Aquitaine. ${ }^{39}$ If the two men are 
related, it could be that Petrus Roselli was of southern French origin. The broad diffusion of this single mass, and the fact that nearly all sources attribute the work to Roselli, could indicate that he was a composer of some renown in his lifetime. It seems unlikely that the apparent popularity of this mass was due simply to its allusion to the famous Josquin song. ${ }^{40}$ For example, the eponymous mass by Mathurin Forestier did not enjoy such a comparable diffusion, although it is much more intimately connected with Josquin's song, its material pervading moreover each mass movement, and not just one, as in Roselli's mass.

Antico also figures prominently among Petreius' sources. This is the case at least for Josquin's Missa de beata virgine and for Brumel's Missa À l'ombre d'ung buissonet. ${ }^{41}$ Moulu's mass Duarum facierum is also transmitted by an Italian source, in this case Giunta $1522 .{ }^{42}$ However, this is not the source Petreius used, as Anna Pranger convincingly demonstrated by comparing the readings of a few passages from Moulu's mass in the various sources. For example, in the Sanctus, Giunta gives four additional measures in the tenor, causing a misalignment with the other voices; this and other errors in Giunta's readings do not occur in Petreius. ${ }^{43}$ Petreius' title Duarum facierum also suggests that Giunta's edition was not his exemplar. Rather than this title, Giunta gives a canonic inscription in macaronic French, Si vous voulem [sic] avoir Misse de cours, Cantés sens pauses en sospir sende cours, which suggests the possibility of performing a faster mass ('misse de cours') if sung without rests ('sens pauses'). ${ }^{44}$ Petreius also gives a canonic inscription suggesting a performance without rests, given in an elegant Latin hexameter Tolle moras, placido maneant suspiria cantu, an allusion to Lucan. ${ }^{45}$ The table of contents gives the title Missa duarum facierum $\mathcal{E}$ plus. Canitur enim vel cum pausis vel sine pausis ('Mass of two or more appearances; for it is sung either with or without rests') (see Table 6.1). But where did Petreius get the title Duarum facierum from? Only three earlier sources survive. The first is Bologna Q.25, compiled in Italy between 1525 and 1550, according to Joshua Rifkin, of which only the altus and tenor partbooks are extant. ${ }^{46}$ Second is the choirbook Cambrai 3 , redacted at Cambrai cathedral between 1526 and 1530. Third is the choirbook 's-Hertogenbosch 72B, copied in Brussels or Mechelen around 1530 by the Alamire workshop for the Confraternity of Our Lady in 's-Hertogenbosch. Of these, only Cambrai 3 and 's-Hertogenbosch 72B carry a title above the mass: $A$ deux visaiges ou plus in Cambrai 3, and La nouvelle messe de Molu à deux visaige [s] ou plus in 's-Hertogenbosch $72 \mathrm{~B} .{ }^{47}$ Both additionally have the canonic inscription to be found in Giunta, but this time in more correct French (Se vous voullés avoer messe de cort chantés sans pauses en suspirant de court), which in 's-Hertogenbosch 72B is written vertically on the left side of the folio, whereas Alma redemptoris, the title of the antiphon on which the mass is actually based, is underlaid to the superius and tenor. ${ }^{48}$ If it is clear that Giunta 1522 has a corrupted version of the French canon to be found in the two manuscripts, it is even clearer that the Latin title Duarum facierum in Petreius is a translation of the French $\grave{A}$ deux visaiges. Since Petreius has both a Latinised paraphrase of the canon and a Latin version of the motto-like title, it is also clear that he must have had access to a source that, like 's-Hertogenbosch 72B, contained both. This hypothetical source may have originated within the cultural orbit of the French royal court, with which Moulu was associated. I was not able to check Cambrai 3, but the reading in 's-Hertogenbosch 72B is quite close to Petreius, so both must have a common ancestor better than that available to Giunta. In Petreius' book, Moulu's mass follows another conceived on the principle of multiple performance possibilities: Okeghem's Missa Cuiusvis toni (see Table 6.1). This cannot have happened by chance, even if masses based on constructivist devices abound in this edition. 


\section{Conclusion}

The three libri missarum here examined establish a kind of repertory or canon of exemplary works of great masters, mostly of past generations. This is especially so for Petreius and Formschneider/Ott, in whose anthologies Josquin occupies a place of honour. Rhau, on the other hand, with a didactic aim in mind, collects masses of medium length which are less challenging to perform. However even he cannot resist a hint at the French master, perhaps with a wink at his friend Martin Luther, who praised Josquin's music as 'flow[ing] out in a joyful, pleasing and mild way, and is not forced or hidebound by the rules, just like the song of the finch' ${ }^{49}$

\section{Source abbreviations}

\section{Manuscripts}

Bayeux: Paris, Bibliothèque nationale de France, f. fr. 9346

Berlin 40013: Kraków, Biblioteka Jagiellońska, olim Berlin, Staatsbibliothek Preußischer Kulturbesitz Z 13

Berlin 40021: Staatsbibliothek zu Berlin - Preußischer Kulturbesitz, MS Mus. 40021

Bologna Q. 25: Museo Internazionale e Biblioteca della Musica di Bologna, MS Q.25

Cambrai 3: Cambrai, Médiathèque municipale MS 3

Cambrai 4: Cambrai, Médiathèque municipale MS 4

Capp. Sist. 16: Città del Vaticano, Biblioteca Apostolica Vaticana, MS Cappella Sistina 16

Capp. Sist. 39: Città del Vaticano, Biblioteca Apostolica Vaticana, MS Cappella Sistina 39

Gotha A.98: Forschungsbibliothek Gotha, Schloss Friedenstein (olim Landesbibliothek), MS Chart. A. 98

's-Hertogenbosch 72B: 's-Hertogenbosch, Archief van de Illustre Lieve Vrouwe Broederschap MS 72B

's-Hertogenbosch 72C: 's-Hertogenbosch, Archief van de Illustre Lieve Vrouwe Broederschap MS 72C

Jena 4: Jena, Universitätsbibliothek MS 4

Jena 21: Jena, Universitätsbibliothek MS 21

Jena 36: Jena, Universitätsbibliothek MS 36

Leipzig 51: Leipzig, Universitätsbibliothek, MS Thomaskirche 51 (1-2) (olim III A.a. 22-23)

Munich 7: Munich, Bayerische Staatsbibliothek, Mus. MS 7

Nuremberg 83795: Nuremberg, Bibliothek des Germanischen Nationalmuseums, MS 83795

Rostock XVI-49: Universitätsbibliothek Rostock, Mus. Saec. XVI-49

San Petronio A.31: Bologna, Archivio Musicale di S. Petronio MS A.XXXI

San Petronio A.46: Bologna, Archivio Musicale di S. Petronio MS A.XXXXVI

Toledo 19: Archivo y Biblioteca Capitular de la Catedral Metropolitana, MS 19

Weimar B: Bibliothek der Evangelisch-Lutherischen Kirchengemeinde, MS B

\section{Printed sources}

Antico 1516: Liber quindecim missarum electarum quae per excellentissimos musicos compositae fuerunt (Rome: Andrea Antico, 1516)

Canti B: Canti B numero cinquanta (Venice: Ottaviano Petrucci, 1502) 
Formschneider/Ott 1539: Missae tredecim quatuor vocum a praestantissimis artificibus compositae (Nuremberg: Hieronymus Grapheus, 1539), vdm 43

Giunta 1522: Missarum decem a clarissimis musicis compositarum nec dum ante exceptis tribus editarum (Roma: Giovanni Giunta, 1522)

Moderne 1532: Liber decem missarum a praeclaris musicis contextus, nunquam antehac in lucem aeditus. Quarum nomina et autores sub sequentis paginae index commonstrat (Lyons: Jacques Moderne, 1532)

Petreius 1539: Liber quindecim missarum, a praestantissimis musicis compositarum, quarum nomina unà cum suis autoribus sequens pagina commonstrat (Nuremberg: Johann Petreius, 1539), vdm 42

Rhau 1541: Opus decem missarum quatuor vocum, in gratiam scholarum atque adeo omnium musices studiosorum (Wittenberg: Georg Rhau, 1541), vdm 1019

Berg and Neuber 1549: Der ander Teil des außbunds kurtzweyliger frischer Teudtscher Liedlein/ zu singen sehr lustig / mit etlichen Newen Liedlein gemehret (Nuremberg: Berg and Neuber, 1549), vdm 1134

\section{Notes}

1 Petreius began by printing two volumes of lute music by Neusidler, then published two motet books and a broadsheet by Senfl. Formschneider started with two volumes of instrumental and lute music, in this case by Gerle, following with three Lieder books by Senfl, Finck and others, a Magnificat volume by Senfl, two motet anthologies and a volume of three-voice mostly German songs. Rhau, on the other hand, had mainly published liturgical music for the Passion, Easter and Vespers, in addition to a motet book by several authors. Further on Petreius, see Keunecke, 'Johannes Petreius'; Teramoto and Brinzing, Katalog der Musikdrucke; concerning Formschneider, see, in particular, Lenckner, 'Formschneider in Nürnberg'; Gustavson, 'Novum et insigne opus musicum'; on Rhau, see Cuyler, 'Opus decem missarum'; Seebass, 'Venus'; Heidrich, 'Georg Rhau'. See moreover the respective entries in MGG and Grove Music Online.

2 See Gustavson, 'Formschneider', accessed on 17 January 2019.

3 ' [...] ut monumenta insignium Musicorum non solum in plurium manus vulgarentur, sed etiam conservarentur ad posteritatem', Missae tredecim quatuor vocum, edited by Hans Ott (Nuremberg: Formschneider 1539), tenor partbook, AA2 .

4 See Meyer, Zwischen Kanon und Geschichte, 89-93.

5 See Schlagel, 'Fortune's Fate', 195 and 206-207. For possible reasons as to why Ott's Josquin transmission is so unsatisfying, see Meyer, Zwischen Kanon und Geschichte, 92-93.

6 Fallows, Josquin, 268-269 doubts that Josquin wrote the Missa Une Musque de Biscaye.

7 The convincing attribution of this mass to Bauldeweyn was first made by Sparks, The Music of Noel Bauldeweyn, and was adopted by the editors of the New Josquin Edition (NJE), who accordingly excluded it from their edition. See NJE 3, XIII and Critical Commentary, 47-52.

8 This double ascription in Formschneider/Ott was also noted by Meconi, Pierre de la Rue, 279 and 320, who, however, did not mention that the la Rue attribution is only recorded in the contratenor. For a discussion of this ascription, see Lindmayr-Brandl, 'Pierre de la Rue's Posthumous Career'.

9 On these masses see, respectively, Francesco de Layolle: Collected Works, vol. 6 (1973), XV (critical apparatus) and 1-20 (music) and Crawford, 'Reflections on Some Masses', 84-87; Antonii Brumel opera omnia, vol. 4, edited by Barton Hudson (1970), XV-XVI (critical apparatus) and 52-64 (music); Blackburn, 'The Lupus Problem', 42 and 108-122; Vendramini, 'Le cantus firmus', 37-38 and 39-41. See, additionally, the relevant articles in MGG and Grove Music Online.

10 See Crawford, 'Reflections on Some Masses', 84.

11 In Moderne 1532, 63v-73r. See Blackburn, 'The Lupus Problem', 108-109.

12 This is moreover indirectly shown by the almost identical wording of the last part of the title in the two mass anthologies: ... Quarum nomina et autores sub sequentis paginae index commonstrat (Moderne), and ... quarum nomina unà cum suis autoribus sequens pagina commonstrat (Petreius). On Petreius' print, see also Pranger, 'Luther's Polyphony'. 
13 See Elders, Josquin Des Prez and His Musical Legacy, 44.

14 On Josquin's 'canonization' in sixteenth-century Germany, see especially Meyer, Zwischen Kanon und Geschichte and Schlagel, 'Fortune's Fate'.

15 On Rener's masses, see Kindermann, 'Die Messen Adam Reners'; a modern edition is contained in Adam Rener, Gesamtausgabe/Collected Works. On Rener more generally, see the respective entries in Grove Music Online and MGG Online.

16 See Noblitt, 'A Reconstruction', 20. On Leipzig 51 see also, more generally, Orf, Die Musikhandschriften especially $35,107-121$ and 141-150.

17 See DIAMM, https://www.diamm.ac.uk/sources/2463/\#/, accessed on 5 February 2019.

18 This, according to Louise Cuyler, was perhaps not casual, 'but the deliberate substitution of a word likely to have meaning for Rhaw's German clients'. See Cuyler, The Emperor Maximilian I and Music, 144, fn. 1. On the mass in general, see Heinrich Isaac: Opera omnia, vol. 7 (1984), XLXLIII (Critical Apparatus) and 114-134 (Music), in addition to Staehelin, Die Messen Heinrich Isaacs, passim. On Berlin 40021 see particularly Just, Der Mensuralkodex Mus. ms. 40021 and Der Kodex Berlin 40021.

19 See Staehelin, Die Messen Heinrich Isaacs, 3: 56-59; Jürgen Heidrich, 'Heinrich Isaacs (?) Missa Carminum', seriously questions Isaacs authorship, on account of its transmission and its rather mediocre compositional quality.

20 On Antico in general, see Chapman, 'Andrea Antico'. On the Liber quindecim missarum, see more specifically Fenlon, Music, Print and Culture, 15, 28, 29-34, 50, 55-56 and 60; Franchi, 'Protagonisti dell'editoria musicale romana', 20-22.

21 See also Heidrich, 'Die polyphone Messe', 297. It is in this context significant that none of the masses in the Opus decem missarum figures in a table of liturgical music prescribed for the church of St. Marien in Wittenberg around 1543/44, the very church in which Luther used to preach: see Menzel, 'Ain herlich Ampt in figuris', 545-547.

22 Rhau employs a G3 clef for most soprano parts of his mass collection, including Roselli's mass, though the much more current $\mathrm{C} 1$ clef would have had the same meaning. Rhau's high clef choice seems rather unusual; within the printed sources examined here, it is only to be found elsewhere in the spurious Josquin mass Da pacem in Formschneider/Ott 1539. Rhau also employs the G3 clef extensively in most of his other musical editions. However, a determination of incidence of the G clef in contemporary manuscript and printed music is beyond the scope of the present chapter.

23 Without going into detail Heidrich, 'Die polyphone Messe', 295, surmised that the Walter manuscripts were the basis for Rhau's mass edition.

24 See Gerhardt, Die Torgauer Walter-Handschriften, 80-81.

25 Kyrie, Gloria and Credo were copied in A.46, whereas Sanctus and Agnus were entered in A.31. For these manuscripts, see Tirro, 'La stesura del testo nei manoscritti di Giovanni Spataro', 52 (A.31); Tirro, Renaissance Musical Sources, 11, 15fn, 17-18, 21, 22fn, 23, 46-49 and 52 (A.31); 10, 11, 16-17, 21, 34, 47 and 49-55 (A.46).

26 See Antonii Brumel opera omnia, XIII-XIV (critical apparatus) and 1-34 (music).

27 For the chant sources used by Rener and Brumel, see Liber Usualis, 58-59 and 64-66 respectively.

28 On Rhau's 'improved' text placement, see Staehelin, Die Messen Heinrich Isaacs, 3: 56.

29 Note that the bassus of this Credo has been erroneously entered into the tenor partbook.

30 For a comprehensive and updated list of all sources, see Senfl Catalogue Online, accessed on 18 February 2019.

31 See Ludwig Senfl: Sämtliche Werke. Band I, 112.

32 For a modern edition of this mass, see Matthaeus Pipelare: Opera omnia, vol. 2, 11-22, critical commentary at IX. Concerning Jena 21, see The Treasury of Petrus Alamire, 103-105.

33 See Rhau 1541, tenor, fol. Aij ${ }^{\text {: }}$ Profero nunc illis [scil. Studiosis ac amatoribus Musices] decem Missas, cum elegantes ac suaves, tum etiam per breves [...].

34 See Chizzali and Heidrich, 'Jena: Musikhandschriften', accessed on 19 February 2019.

35 For the transmission of Isaac's works in central European sources, see the list of sources and the critical apparatus in Isaac: Opera omnia, vol. 7, XL-XLIII (critical apparatus); 114-134 (music); Staehelin, Die Messen Heinrich Isaacs, passim and Staehelin, 'Isaac', accessed on 28 January 2019.

36 For this mass, see the modern edition with critical commentary in Mathurini Forestier: Opera omnia and Milsom and Saunders, 'Who Composed the Missa Cueur langoreulx?', 145-154, with some biographical extrapolations on Forestier at 160 . See also more generally MacCracken, "The Sacred Music of Mathurin Forestier', esp. 349 and 351-353. 
37 See NJE 28: Secular Works for Four Voices, edited by David Fallows, Critical Commentary, 91.

38 See in Heartz, Pierre Attaingnant, 100.

39 See in Imprimeurs \& libraires parisiens du XVI e siècle, 137, 160-161, 163, 294.

40 Josquin's song, first transmitted à 4 in Canti B, is itself an arrangement of a 'popular' melody transmitted in Bayeux.

41 See Pranger, 'Luther's Polyphony', 49.

42 On the editions of the Giunta family, see Pettas, The Giunti of Florence.

43 See Pranger, 'Luther's Polyphony', 54-55.

44 See Kurtzman and Schnoebelen, 'A Catalogue of Mass, Office, and Holy Week Music'.

45 See Blackburn and Holford-Strevens, 'Juno's Four Grievances', 164. The same Latin canon with the Duarum facierum title is present in Rostock XVI-49, which is obviously derived from Petreius 1539.

46 See Census-Catalogue, 1: 77.

47 For Cambrai 3, see Coussemaker, Notice sur les collections, 24-32, the Moulu mass being briefly mentioned at 28-29. Note, however, that the author misread the title above the mass as $\dot{A}$ deux villaiges ou plus instead of $\grave{A}$ deux visaiges ou plus; for 's-Hertogenbosch 72B see Roelvink, 'The Alamire Manuscripts' and The Treasury of Petrus Alamire, 81, where a detail of fol. $154^{\mathrm{v}}$ containing the beginning of the mass is reproduced. It is possible that Bologna Q.25 also had an inscription in one of the lost partbooks, but in the absence of these books, this cannot be verified.

48 See ibid., where, however, only the superius is visible. The same canonic inscription is visible in a much later source of this mass, Capp. Sist. 39, copied between 1558 and 1563 (see DIAMM, https://www.diamm.ac.uk/sources/2633/\#/, accessed on 22 February 2019 and Schiltz, Music and Riddle Culture, 128, fn. 138). In this connection it is interesting to observe that another Alamire manuscript compiled for the Illustre Lieve Vrouwe Broederschap in den Bosch ('s-Hertogenbosch 72C) has concordances with Cambrai 4, a source contemporary with Cambrai 3 and partially compiled by the same scribes (see DIAMM https://www.diamm.ac.uk/sources/1663/\#/, accessed on 22 February 2019). Whether this might imply some form of repertoire exchange between Cambrai cathedral and the collegiate church of 's-Hertogenbosch lies outside the scope of the present chapter.

49 Luther, Tischreden, 2: 11-12, no. 1258: 'Sic Deus praedicavit euangelium etiam per musicam, ut videtur in Iosquin, des alles composition frohlich, willig, milde herausfleust, ist nitt zwungen und gnedigt per regulas, sicut des fincken gesang'. See also Østrem, 'Luther, Josquin and des fincken gesang', 51; Meyer, Zwischen Kanon und Geschichte, 114-122.

\section{References}

Blackburn, Bonnie J. 'The Lupus Problem'. PhD dissertation, University of Chicago, 1970.

Blackburn, Bonnie J. and Leofranc Holford-Strevens. 'Juno's Four Grievances: The Taste for the Antique in Canonic Inscriptions'. In Musikalische Quellen - Quellen zur Musikgeschichte. Festschrift für Martin Staehelin zum 65. Geburtstag, edited by Jürgen Heidrich, Hans-Joachim Marx and Ulrich Konrad. Göttingen: Vandenhoeck \& Ruprecht, 2003, 159-174.

Brumel, Antonii opera omnia, edited by Armen Carapetyan and Barton Hudson. Corpus Mensurabilis Musicae 5/1-5. [Rome]: American Institute of Musicology, 1951-1972.

Chapman, Catherine W. 'Andrea Antico'. PhD dissertation, Harvard University, 1964.

Chizzali, Michael and Jürgen Heidrich. 'Jena: Musikhandschriften'. In MGG Online (2016). https:// www.mgg-online.com/mgg/stable/51093.

Coussemaker, Charles Edmond Henri de. Notice sur les collections musicales de la Bibliothèque de Cambrai. Paris: Techener, 1843.

Crawford, David. 'Reflections on Some Masses from the Press of Moderne'. The Musical Quarterly 58/1 (1972): 82-91.

Cuyler, Louise E. The Emperor Maximilian I and Music. London: Oxford University Press, 1973.

Cuyler, Louise E. 'Georg Rhaw's Opus decem missarum, 1541. Some Aspects of the Franco-Flemish Mass in Germany'. In Renaissance-Muziek 1400-1600: donum natalicium René Bernard Lenaerts. 
Musicologica Lovaniensia. Leuven: Katholieke Universiteit, Seminarie voor Muziekwetenschap, 1969, 71-81.

Der Kodex Berlin 40021: Staatsbibliothek Preussischer Kulturbesitz Berlin, Mus. ms. 40021. 3 vols. edited by Martin Just. Das Erbe deutscher Musik 77; Abteilung Mittelalter 15. Kassel: Bärenreiter, 1991.

Elders, Willem. Josquin Des Prez and His Musical Legacy: An Introductory Guide. Leuven: Leuven University Press, 2013.

Fallows, David. Josquin. Turnhout: Brepols, 2009.

Fenlon, Iain. Music, Print and Culture in Early Sixteenth-Century Italy. The Panizzi Lectures 1994. London: The British Library, 1995.

Forestier, Mathurini (fl. c. 1504-1541): Opera omnia, edited by Nors S. Josephson and Thomas G. MacCracken. Corpus Mensurabilis Musicae 104. Neuhausen: American Institute of Musicology/ Hänssler Verlag, 1996.

Francesco de Layolle: Collected Works, edited by Frank A. D'Accone. Music of the Florentine Renaissance 6. Corpus Mensurabilis Musicae 32/3-6. [Rome]: American Institute of Musicology, 1969-1973.

Franchi, Saverio. 'Protagonisti dell'editoria musicale romana nella prima metà del Cinquecento: Andrea Antico, Giacomo Giunta, Valerio Dorico e Antonio Barrè'. Recercare 26/1-2 (2014): 13-55.

Gerhardt, Carl. Die Torgauer Walter-Handschriften: Eine Studie zur Quellenkunde der Musikgeschichte der deutschen Reformationszeit. Kassel, etc.: Bärenreiter, 1949.

Gustavson, Royston. 'Formschneider, Formschneyder, Grapheus, Enderlin, Enndres, Andreae, Andre, Andree, Andres, Hieronymus, Jeronimus'. In MGG Online (2008). https://www.mgg-online.com/ $\mathrm{mgg} / \mathrm{stable} / 47653$.

Gustavson, Royston. 'Hans Ott, Hieronymus Formschneider, and the Novum et insigne opus musicum (Nuremberg, 1537-1538)'. PhD dissertation, University of Melbourne, 1998.

Heartz, Daniel. Pierre Attaingnant, Royal Printer of Music: A Historical Study and Bibliographical Catalogue. Berkeley and Los Angeles: University of California Press, 1969.

Heidrich, Jürgen. ‘Die polyphone Messe in den Drucken von Georg Rhau'. In Polyphone Messen im 15. und 16. Jahrhundert, edited by Andrea Ammendola, Daniel Glowotz and Jürgen Heidrich. Göttingen: V\&R unipress, 2012, 285-303.

Heidrich, Jürgen. 'Georg Rhau als Wittenberger Musikaliendrucker und -verleger'. In Buchdruck und Buchkultur im Wittenberg der Reformationszeit, edited by Stefan Oehmig. Schriften der Stiftung Luthergedenkstätten in Sachsen-Anhalt 21. Leipzig: Evangelische Verlagsanstalt, 2015, 191-203.

Heidrich, Jürgen. 'Heinrich Isaacs (?) Missa Carminum. Überlieferung-Werkgestalt-Gattungskontext'. Jahrbuch der Ständigen Konferenz Mitteldeutsche Barockmusik 2001 (2003): 123-139.

Imprimeurs \& libraires parisiens du XVI eiècle. Ouvrage publié d'après les manuscrits de Philippe Renouard, edited by the Service des travaux historiques de la Ville de Paris avec le concours de la Bibliothèque nationale. Vol. 2. Paris: Service des travaux historiques de la Ville de Paris, 1969.

Isaac, Heinrich (ca. 1450-1517): Opera omnia, edited by Edward R. Lerner. Corpus Mensurabilis Musicae 65/1-8. Neuhausen-Stuttgart: American Institute of Musicology, 1974-2011.

Just, Martin. Der Mensuralkodex Mus. ms. 40021 der Staatsbibliothek Preußischer Kulturbesitz Berlin. Untersuchungen zum Repertoire einer deutschen Quelle des 15. Jahrhunderts. 2 vols. Würzburger musikhistorische Beiträge. Tutzing: Hans Schneider, 1975.

Keunecke, Hans-Otto. 'Johannes Petreius (1496/97-1550)'. Mitteilungen des Vereins für Geschichte der Stadt Nürnberg 69 (1982): 110-129.

Kindermann, Jürgen. 'Die Messen Adam Reners. Ein Beitrag zur Musikgeschichte des frühen 16. Jahrhunderts'. PhD dissertation, Christian-Albrechts-Universität Kiel, 1962. 
Kurtzman, Jeffrey, and Anne Schnoebelen. 'A Catalogue of Mass, Office, and Holy Week Music Printed in Italy, 1516-1770'. Journal of Seventeenth-Century Music, JSCM Instrumenta 2 (2013), http://sscm-jscm.org/instrumenta/instrumenta-volumes/instrumenta-volume-2/, accessed 29 January 2019.

Lenckner, Georg. 'Hieronymus Andrae, Formschneider in Nürnberg, und M. Bernhard Bubenleben, Pfarrer in Mergentheim'. Württembergisch Franken, Neue Folge, 28-29 (1953-1954): 152-154.

The Liber Usualis with Introduction and Rubrics in English, edited by the Benedictines of Solesmes. Tournai: Desclée \& Cie, 1956.

Lindmayr-Brandl, Andrea. 'Pierre de la Rue's Posthumous Career in German prints'. In Pierre de la Rue Studies, edited by David J. Burn, Honey Meconi, and Christiane Wiesenfeldt (forthcoming).

Luther, Martin. Tischreden, 1531-46. Zweiter Band. Tischreden aus den dreißiger Jahren. 6 vols. D. Martin Luthers Werke kritische Gesamtausgabe, with a preface by Karl Drescher. Weimar: Böhlau, 1913.

MacCracken, Thomas G. 'The Sacred Music of Mathurin Forestier'. Yearbook of the Alamire Foundation 5 (2003): 349-362.

Meconi, Honey. Pierre de la Rue and Musical Life at the Habsburg-Burgundian Court. Oxford: Oxford University Press, 2003.

Menzel, Stefan. “Ain herlich Ampt in figuris': Sacred Polyphony at St. Marien in Wittenberg 1543/44'. Early Music 45/4 (2017): 545-557.

Meyer, Michael. Zwischen Kanon und Geschichte: Josquin im Deutschland des 16. Jahrhunderts. Épitome musical. Turnhout: Brepols, 2016.

Milsom, John and Zoe Saunders. 'Who Composed the Missa Cueur langoreulx? The Case for Mathurin Forestier'. Journal of the Alamire Foundation 8/1 (2016): 139-161.

New Josquin Edition 3: Masses Based on Gregorian Chant, edited by Willem Elders. Utrecht: Koninklijke Vereniging voor Nederlandse Muziekgeschiedenis, 2003.

Noblitt, Thomas. 'A Reconstruction of Ms. Thomaskirche 51 of the Universitätsbibliothek Leipzig (olim III, A.a. 22-23)'. Tijdschrift van de Vereniging voor Nederlandse Muziekgeschiedenis 31/1 (1981): $16-72$.

Orf, Wolfgang. Die Musikhandschriften Thomaskirche Mss. 49/50 und 51 in der Universitätsbibliothek Leipzig. Leipzig: VEB Deutscher Verlag für Musik, 1977.

Østrem, Eyolf. 'Luther, Josquin and des fincken gesang'. In The Arts and the Cultural Heritage of Martin Luther, edited by Eyolf Østrem et al. Copenhagen: Museum Tusculanum Press, 2002, 51-80.

Pettas, William A. The Giunti of Florence, a Renaissance Printing and Publishing Family. A History of the Florentine Firm and a Catalogue of the Editions. New Castle, DE: Oak Knoll Press, 2013.

Pipelare, Matthaeus: Opera omnia, edited by Ronald Cross. Vol. 2. Corpus Mensurabilis Musicae 34. [Rome]: American Institute of Musicology, 1967.

Pranger, Anna. 'Luther's Polyphony: Petreius's Liber quindecim missarum in Protestant Nuremberg'. PhD dissertation, University of Cincinnati, 2014.

Rener Adam: Gesamtausgabe/Collected Works. 2 vols, edited by Robert L. Parker. Brooklyn, NY: Institute of Mediaeval Music, 1964-1976.

Roelvink, Véronique. 'The Alamire Manuscripts of the Illustre Lieve Vrouwe Broederschap in 's-Hertogenbosch: New Facts and Considerations'. In The Burgundian-Habsburg Court Complex of Music Manuscripts (1500-1535) and the Workshop of Petrus Alamire, Colloquium Proceedings, Leuven, 25-28 November 1999, edited by Bruno Bouckaert and Eugeen Schreurs. Yearbook of the Alamire Foundation 5 (2003): 203-213. 
Schiltz, Katelijne. Music and Riddle Culture in the Renaissance. Cambridge: Cambridge University Press, 2015.

Schlagel, Stephanie. 'Fortune's Fate: Josquin and the Nürnberg Mass Prints of 1539'. In Josquin and the Sublime. Proceedings of the International Josquin Symposium at Roosevelt Academy, Middelburg, 12-15 July 2009, edited by Albert Clement and Eric Jas. Épitome musical. Turnhout: Brepols, 2011, 191-209.

Seebass, Tilman. 'Venus und die Musikwissenschaft oder von der Universalität eines reformatorischen Buchmachers (Georg Rhau)'. In Totum me libris dedo. Festschrift zum 80. Geburtstag von Adolf Seebass, edited by Alain Moirandat, Heide Spilker and Verena Tammann. Basel: Haus der Bücher, 1979, 187-199.

Senfl Catalogue Online /New Senfl Edition. Ludwig Senfl - Forschugsprojekt, Universität Wien, http:/ / www.senflonline.com.

Senfl, Ludwig: Sämtliche Werke. Band I, Sieben Messen zu vier bis sechs Stimmen, edited by Edwin Löhrer and Otto Ursprung. Wolfenbüttel: Möseler Verlag, 1962.

Sparks, Edgar H. The Music of Noel Bauldeweyn. New York: American Musicological Society, 1972.

Staehelin, Martin. Die Messen Heinrich Isaacs. 3 vols. Publikationen der Schweizerischen Musikforschenden Gesellschaft II / Publications de la Société Suisse de Musicologie II/28. Bern: Paul Haupt, 1977.

Staehelin, Martin. 'Isaac, Isaak, Ysac, Ysach, Yzac u. ̈̈., Heinrich, Henrich, Henricus, Arrigo di Fiandra/de Alemania, Arrigo d'Ugo/Ugonis, Arrigo Tedesco u.ä.'. In MGG Online (2016). https://www.mggonline.com/mgg/stable/11536.

Teramoto, Mariko and Armin Brinzing. Katalog der Musikdrucke des Johannes Petreius in Nürnberg. Catalogus musicus 14. Kassel: Bärenreiter, 1993.

Tirro, Frank. 'La stesura del testo nei manoscritti di Giovanni Spataro'. Rivista Italiana di Musicologia 15 (1980): 31-70.

Tirro, Frank. Renaissance Musical Sources in the Archive of S. Petronio in Bologna. Vol. I: G. Spataro's Choirbooks. Rome: American Institute of Musicology, 1986.

The Treasury of Petrus Alamire. Music and Art in Flemish Court Manuscripts 1500-1535, edited by Herbert Kellman. Ghent/Amsterdam: Ludion, 1999.

Vendramini, Cécile. 'Le cantus firmus dans les six messes Hercules dux Ferrariae'. In De l'église à la salle de concert, edited by Édith Weber. Itinéraires du cantus firmus 4. Paris: Presses de l’Université de Paris-Sorbonne, 2001, 37-48. 